\title{
The endocrine lung and its response to hypoxia
}

\author{
J R Gosney
}

The endocrine system of the lungs, in common with other components of the diffuse endocrine system, comprises a dispersed population of peptide and amine secreting cells which acts in concert with the nervous system and systemic mechanisms of endocrine control to maintain homeostasis. ${ }^{1}$ Of all the roles proposed for the pulmonary endocrine system - and very little is known for certain - that of monitoring the concentration of gases in the airways has been most often suggested. The purpose of this paper is to review the evidence for this putative function.

\begin{abstract}
Morphological aspects
As knowledge of the structure of the pulmonary endocrine system has increased, it has become clear that it would be ideally suited to have chemoreception as one of its functions. Over 40 years ago Fröhlich ${ }^{2}$ suggested that the arrangement of some pulmonary endocrine cells as innervated clusters, which he thought resembled taste buds, made monitoring of intrapulmonary gases a likely role. Numerous studies in lower mammals have since served to support the possibility. In such species these innervated clusters, now generally known as neuroepithelial bodies, ${ }^{3}$ are the predominant form of arrangement of pulmonary endocrine cells and are evenly distributed although concentrated where airways branch. ${ }^{45}$ They have a complex innervation, involving both afferent and efferent nerve endings, ${ }^{67}$ and relay in and are modulated by the vagus. ${ }^{89}$
\end{abstract}

\section{Acute short term hypoxia}

The first direct evidence of a chemoreceptive role for neuroepithelial bodies came when Lauweryns and Cokelaere ${ }^{10}$ described how, in young rabbits, exposure of these structures to acute hypoxia led to their degranulation. Later studies demonstrated how this degranulation of neuroepithelial bodies was specific for hypoxia, occurring in response to neither hyperoxia, hypercapnia, nor hypoxaemia, ${ }^{11-14}$ and how it induced synaptic activity in the nerve endings in contact with them. ${ }^{15}$ Most recently Cutz et $a l^{16}$ have shown an exocytotic response to acute hypoxia of isolated fetal rabbit neuroepithelial bodies in culture, confirming the phenomenon previously shown only in vivo.

The consequences of any centripetal vagal transmission resulting from this hypoxiainduced receptor activity are quite unclear. Almost any aspect of pulmonary physiology could theoretically be affected by initiation of activity in reflex arcs, including vascular or bronchial tone and secretion of mucus or other products of bronchial glands and pulmonary epithelium. Presently, however, nothing is known about the efferent limb of the response to acute hypoxia.

\section{Chronic unremitting hypoxia}

The role of the pulmonary endocrine system in mediating adjustments to chronic, unremitting hypoxia lasting from weeks to years - as opposed to that discussed above, which is acute in onset and of a duration measured in minutes - is uncertain. It is seen, of course, as an important consequence of a number of common pulmonary disorders, most particularly in chronic bronchitis and emphysema. Unfortunately, changes in the pulmonary endocrine system in lungs affected by diseases like this, and which might be due to hypoxia per se, are impossible to separate from those caused by other aspects of the pathology of such conditions, particularly the inflammation and repair and regeneration of the tissues of the lung following pulmonary injury. There are, however, two situations in which the response of the pulmonary endocrine system to unremitting hypoxia in relative isolation can be studied. The first is in the laboratory, where animals can be exposed to hypobaric or normobaric hypoxia in chambers. The second is in the naturally hypoxic environment of the world's high places.

\section{STUDIES IN THE LABORATORY}

No consensus has emerged concerning the effects of hypoxia on the pulmonary endocrine system of animals exposed to reduced levels of oxygen in the laboratory. Some have described reduced numbers of pulmonary endocrine cells under such circumstances, ${ }^{1718}$ some report increased numbers, ${ }^{1920}$ and others describe no change in either direction. ${ }^{20-23}$

Unfortunately, the species used, the duration and severity of hypoxia, and the methods of identifying and quantifying pulmonary endocrine cells varied widely between these studies, so they are impossible to compare meaningfully. More subtle studies which examined the effects of hypoxia on one of the products of these cells - calcitonin gene-related peptide - have revealed an interesting effect, although its significance is presently uncertain. In these, exposure of rats for 21 days to an environment containing just $10 \%$ oxygen caused an increase in the concentration of this peptide in pulmonary endocrine cells of the order of $15-20 \%,{ }^{2324}$ a change which was subsequently shown to result from a decrease in its release rather than an increase in its synthesis. ${ }^{25}$ 


\section{STUDIES AT HIGH ALTITUDE}

In 1977 Taylor $^{26}$ described how the lungs of six rabbits from the Peruvian Andes contained more pulmonary endocrine cells, especially neuroepithelial bodies, than those of controls from sea level, a finding confirmed more recently in guinea pigs from the same location. ${ }^{27}$ An investigation of a number of species from different altitudes in the Himalayas ${ }^{28}$ showed no such differences, although numbers were small and the differences between the altitudes at which they had lived were not great.

In 1983 Memoli et $a l^{29}$ published, in abstract form, the results of a study of pulmonary endocrine cells in the lungs of 20 lifelong human residents of $\mathrm{La} \mathrm{Paz}$, Bolivia; increased numbers were reported in six cases. Unfortunately, a recent exhaustive investigation of six pairs of widely sampled lungs from similar subjects ${ }^{30}$ failed to show any differences in the number, content, or distribution of pulmonary endocrine cells when compared with the lungs of subjects from sea level, despite the fact that in three subjects there was pulmonary vascular remodelling typical of that seen in residents at high altitude.

\section{Conclusions}

There seems little doubt that acute hypoxia excites activity in neuroepithelial bodies, although its consequences are unknown. Whether exposure to the chronic hypoxia that occurs in certain cardiorespiratory diseases and at natural high altitude has any effects on the pulmonary endocrine system, as might be expected to occur if hypoxic chemoreception was one of its functions, is unclear. There is evidence, however, that such prolonged exposure might alter the dynamics of the release of its secretory products and sometimes lead to an increase in the number of neuroepithelial bodies.

1 Gosney JR. Pulmonary endocrine pathology: endocrine cells and endocrine tumours of the lung. Oxford: ButterworthHeinemann, 1992

2 Fröhlich F. Die HelleZelle der Bronchialschleimhaut und ihre Beziehungen zum Problem der Chemoreceptoren. Frankfurter $Z$ Pathol 1949;60:517-59.

3 Lauweryns JM, Peuskens JC. Neuroepithelial bodies (neuroreceptor or secretory organs?) in human infant bronchial epithelium. Anat Rec 1972;172:471-82.

4 Hoyt RF, Feldman H, Sorokin SP. Neuroepithelial bodies (NEB) and solitary endocrine cells in the hamster lung. Exp Lung Res 1982;3:299-311.

5 Hoyt RF, Sorokin SP, Feldman H. Small-granule (neuro) endocrine cells in the infracardiac lobe of a hamster lung. Number, subtypes, and distribution. Exp Lung Res 1982; 3:273-98.

6 Lauweryns JM, Cokelaere M, Theunynck P. Neuro-epithelial bodies in the respiratory mucosa of various mammals: a light optical, ultrastructural and histochemical investigation. Z Zellforsch Mikrosk Anat 1972;135:569-92.

7 Lauweryns JM, Cokelaere M, Theunynck P. Serotonin producing neuroepithelial bodies in rabbit respiratory mucosa. ducing neuroepithelial bo $1973 ; 180: 410-3$.

8 Lauweryns JM, Van Lommel A. The intrapulmonary neuroepithelial bodies after vagotomy: demonstration of their sensory neuroreceptor-like innervation. Experientia 1983;39:1123-4.

9 Lauweryns JM, de Bock V, Decramer M. Effects of unilateral vagal stimulation on intrapulmonary neuroepithelial bodies. F Appl Physiol 1987;63:1781-7.

10 Lauweryns JM, Cokelaere M. Hypoxia-sensitive neuro-epithelial bodies. Intrapulmonary secretory neuroreceptors modulated by the CNS. Z Zellforsch Mikrosk Anat 1973; 145:521-40.

11 Lauweryns JM, Cokelaere M, Deleersnyder M, Liebens $M$. Intrapulmonary neuro-epithelial bodies in newborn rabbits. Influence of hypoxia, hyperoxia, hypercapnia, nicrabbits. Influence of hypoxia, hyperoxia, hypercapnia, nic182:425-40.

12 Lauweryns JM, Cokelaere M, Lerut T, Theunynck P. Crosscirculation studies on the influence of hypoxia and hypoxaemia on the neuro-epithelial bodies in young rabbits. Cell Tissue Res 1978;193:373-86.

13 Lauweryns JM, De Bock V, Guelinckx P, Decramer M Effects of unilateral hypoxia on neuroepithelial bodies in rabbit lungs. $\mathcal{F}$ Appl Physiol 1983;55:1665-8.

14 Lauweryns JM, Tierens A, Decramer $M$. Influence of hypercapnia on rabbit intrapulmonary neuroepithelial bodies: microfluorimetric and morphometric study. Eur Respir f 1990;3:182-6.

15 Lauweryns JM, Van Lommel A. Morphometric analysis of hypoxia-induced synaptic activity in intrapulmonary neuroepithelial bodies. Cell Tissue Res 1982;226:201-14.

16 Cutz E, Speirs V, Yeger H, Newman C, Wang D, Perrin DG. Cell biology of pulmonary neuroepithelial bodies validation of an in vitro model $I$. Effects of hypoxia and $\mathrm{Ca}^{2+}$ ionophore on serotonin content and exocytosis of dense-core vesicles. Anat $\operatorname{Rec} 1993 ; 236: 41-52$.

17 Hernandez-Vasquez A, Will JA, Quay WB. Quantitative characteristics of the Feyrter (APUD) cells of the neonatal rabbit lung in normoxia and chronic hypoxia. Thorax 1977;32:449-56.

18 Hernandez-Vasquez A, Will JA, Quay WB. Quantitative characteristics of the Feyrter cells and neuroepithelial bodies of the fetal rabbit lung in normoxia and short term chronic hypoxia. Cell Tissue Res 1978;189:179-86.

19 Keith IM, Will JA. Hypoxia and the neonatal rabbit lung: neuroendocrine cell numbers, 5-HT fluorescence intensity and the relationship to arterial thickness. Thorax 1981;36: 767-73.

20 Pack RJ, Barker S, Howe A. The effect of hypoxia on the number of amine-containing cells in the lung of the adult rat. Eur $\mathcal{F}$ Respir Dis 1986;68:121-30.

21 Moosavi H, Smith P, Heath D. The Feyrter cell in hypoxia. Thorax 1973;28:729-41.

22 Keith IM, Wiley LA, Will JA. Pulmonary neuroendocrine cells: decreased serotonin fluorescence and stable arcells: decreased serotonin fluorescence and stable ar1981;214:201-5.

23 Springall DR, Collina G, Barer G, Suggett AJ, Bee D, Polak $\mathrm{JM}$. Increased intracellular levels of calcitonin gene-related peptide-like immunoreactivity in pulmonary endocrin cells of hypoxic rats. $\mathcal{F}$ Pathol 1988;155:259-67.

24 McBride JT, Springall DR, Winter RJ, Polak JM. Quantitative immunocytochemistry shows calcitonin generelated peptide-like immunoreactivity in lung neuroendocrine cells is increased by chronic hypoxia in the rat. Am ₹ Respir Cell Mol Biol 1990;3:587-93.

25 Springall DR, Polak JM. Calcitonin gene-related peptide and pulmonary hypertension in experimental hypoxia. Anat Rec 1993;236:96-104.

26 Taylor W. Pulmonary argyrophil cells at high altitude. $f$ Pathol 1977;122:137-44.

27 Gosney JR. Pulmonary endocrine cells in native Peruvian guinea-pigs at low and high altitude. F Comp Pathol 1990; 102:7-12.

28 Gosney J, Heath D, Williams D, Deen M, Harris P, Anand $\mathrm{I}$, et al. Pulmonary endocrine cells in various species in the Himalaya. F Comp Pathol 1988;99:93-100.

29 Memoli VA, Linnoila I, Warren WH, Rios-Dalenz J, Gould VE. Hyperplasia of pulmonary neuroendocrine cells and neuroepithelial bodies (abstract). Lab Invest 1983;48:57.

30 Williams D, Heath D, Gosney J, Rios-Dalenz J. Pulmonary endocrine cells of Aymara Indians from the Bolivian Andes. Thorax 1993;48:52-6. 